\title{
SOCIAL NETWORK ANALYSIS ON LEAN PRODUCTION AND WORLD CLASS MANUFACTURING: HOW ARE ASSOCIATED IN THE LITERATURE?
}

\author{
Gustavo Antiqueira Goes \\ UNESP - Univ Estadual Paulista, Brazil \\ E-mail: gustavogoes@tupa.unesp.br \\ Eduardo Guilherme Satolo \\ UNESP - Univ Estadual Paulista, Brazil \\ E-mail: eduardo@tupa.unesp.br \\ Timóteo Ramos Queiroz \\ UNESP - Univ Estadual Paulista, Brazil \\ E-mail: timoteo@tupa.unesp.br \\ Cristiane Hengler Correa Bernardo \\ UNESP - Univ Estadual Paulista, Brazil \\ E-mail: cristiane@tupa.unesp.br \\ Juliana Delgado Martins Raymundo \\ UNESP - Univ Estadual Paulista, Brazil \\ E-mail: Juliana.delgado.martins@gmail.com
}

Submission: 02/01/2017

Revision: 12/01/2017 Accept: 16/01/2017

\section{ABSTRACT}

This paper aims to conduct a Systematic Literature Review (SLR) to identify how to configure the publications that relate WCM and Lean Production issues. Therefore, a search on the Brazilian metasearch portal called CAPES Periodicals was conducted focusing on articles of the last five years. They were identified after screening and filtering a total of 42 articles, which were analyzed. The construction of the network analysis has identified that the issues are still in an initial phase of association, with the characteristic part of decentralizes networks, with some points of greatest association. It was also identified that the theme Lean Production has greater representation between the two topics due its higher use by authors.

Keywords: Interrelation; Social networks; Systemic literature review. 
DOI: 10.14807/ijmp.v8i1.596

\section{INTRODUCTION}

The global competitiveness, seeking increased profitability, has become the main objective of the companies in the current environment due to the expansion of segments in the same production chain. This aspect brings the constant need for improvement of organizational production system, boosting the use of administrative strategies which assist in the selection of appropriate techniques and tools to achieve a better industrial production, ensuring their stay in the market (BORGES; OLIVEIRA; OLIVEIRA, 2013). Every production process, no matter how good are their management, and their activities achieve controlled and planned tasks, it is still possible to identify points to be improved (GOETSCH; DAVIS, 2014).

In this sense, among many existing theories, the approach called World Class Manufacturing (WCM) shows to be efficient with regard to elimination of losses and has been able to enter into organizations that aim to achieve high levels of perfection in their production levels. In concomitant period the WCM approach was to rise the Lean philosophy, known in organizational environments such as Lean Production System and had to cradle the Toyota Production System, which has been studied and applied as a management model to inherit a strong culture that is characterized by the production control through perfect techniques, continuous improvement, and that has brought excellent results to organizations over the years (SMITH, 2011).

The reflection of great importance in the business world can be seen through the quantitative analysis of publications related to topics discussed here. Performing a matter of Lean Production in the Brazilian metasearch portal CAPES Periodicals (Higher Education Personnel Improvement Coordination) are identified 2.623 articles published in peer-reviewed journals over the past five years (2010-2015). Since the search for the subject WCM resulted in a total of 6.070 documents. However, although the large number of studies between these two topics in the literature, there are not available research that shows this interrelationship of WCM approach and the Lean Production System techniques, featuring this regard a research gap.

This way, before these two themes, the Systematic Literature Review (SLR) becomes all-important, as it can provide other researchers find study materials have been finalized and filtered. It also allows time and resources economy, provides mapping in which specific areas the studies are being developed and it is possible 
DOI: 10.14807/ijmp.v8i1.596

and most relevant checking for gaps in the literature that can be explored by other researchers have not yet identified the lack of studies review (CONFORTO; AMARAL; SILVA, 2012). These factors, this research seeks to answer the problem checked: In what areas of study are concentrated scientific research involving topics Lean Production and World Class Manufacturing? In this context, this research has aimed at making a Systematic Literature Review (SLR) to identify how to configure the publications that relate WCM and Lean Production.

For development of the present study it was divided into sections, where the first part deals with the introduction, objectives, found problems, and the importance that justifies this production. The second section consists of literature review, which enabled the explanation and origin of the themes elucidated. The third topic contains the explanation of the adopted methodological concepts, from carrying out the procedures used to collect data as well as construction of the database. The fourth part shows the results. By the end, the fifth and final section reports the considerations of all developed production.

\section{THEORETICAL FOUNDATION: WCM AND LEAN PRODUCTION}

The World Class Manufacturing is among the strategies to enhance the production. Its techniques are based on "concept of zero waste, zero breakdown, zero defects and zero stock" (BORGES; OLIVEIRA; OLIVEIRA, 2013). This strategy becomes suitable for companies looking to minimize costs of its activities, increase its excellence and hence competitiveness across sectors (GAJDZIK, 2013; SOUZA; LIMA, 2003).

The origin of the concept of WCM took place in the 1980s through case studies of successful companies (BORGES; OLIVEIRA; OLIVEIRA, 2013). His term was coined by Hayes and Wheelwright (HAYES; WHEELWRIGHT, 1984) to describe the capabilities developed by Japanese and German companies, which had a higher level of production when compared to other industries. The excellent performance in global competition of these companies generated the term "World Class Manufacturing" (EID, 2009).

The WCM includes success against competitors and organizational profitability in a competitive international environment. His approach is related to the absolute competitive advantage and the best producers (HOSSEINIE; SHIRAZI; 
ASHLOGHI; MEHR, 2012; PALUCHA, 2012) can define this as the best practice. Based on 10 interconnections, called pillars, which relate the manufacturing process and maintain and enable an organization to achieve world class (GAJDZIK, 2013; PALUCHA, 2012; ZIMWARA; GORIWONDO; MHLANGA; CHASARA; CHUMA, 2012). These pillars are divided in: safety, cost deployment, focused improvement, autonomous activities, professional maintenance, logistics, early management, people development and environment, and quality control (GAJDZIK, 2013; PALUCHA, 2012; ZIMWARA; GORIWONDO; MHLANGA; CHASARA; CHUMA, 2012).

Achieve the performance of a world-class organization involves important assignments, including: become a globally successful manufacturer; recognize the business environment and free competition, threats, opportunities and competitive advantages; and prepare and stay in this environment with industrial planning and manufacturing (HOSSEINIE; SHIRAZI; ASHLOGHI; MEHR; AN, 2012).

The competitive advantages pointed to an organization that achieves worldclass are studied and listed in different ways by different authors that characterize points as improved profitability, training, product development, better quality, quick reaction against competitors, production programs, attention to customer needs, reasonable prices, delivery, flexibility, quality management, reducing the supply of goods, cost of production, innovation, strategy, systems and structures, accountability, performance measurement, values and fundamental objectives, culture and competitors (BORGES; OLIVEIRA; OLIVEIRA, 2013; CHIARINI; VAGNONI, VAGNONI, 2014; SCHONBERGER, 1996).

These different features that allow pointing to competitive advantage and classify the organization as a world class result in the attempt by the researchers to establish models to measure and classify an organization such as WCM (HOSSEINIE; SHIRAZI; ASHLOGHI; MEHR; AN, 2012; PALUCHA, 2012; NG; HUNG, 2001; ASKARI, 2004; MOTWANI; KUMAR; KATHAWALE; KATHAWALE; WCM, 1994). Other researches also aimed to identify the critical success factors for the implementation of WCM (XIE, 1995; SVENSSON; KLEFSJO, 2001).

Note, through these studies conducted in various research fronts, there is still need for further elucidate a topic considered again, and it lacks progress in its 
DOI: 10.14807/ijmp.v8i1.596

theory. It is known (PALUCHA, 2012) that the adoption of a management organization, in accordance with the principles of WCM, is based on reliable methods, high quality tools, and extensive involvement of all employees and company managers. Also in the management aspect, Yamashina (2000) cited by (BORGES; OLIVEIRA; OLIVEIRA, 2013) complements the use of WCM is divided into four steps: identify the problem, identify the loss, define the method to be adopted for restoration and control the results.

The elucidated points that depict the WCM as the organizational pursuit of excellence through modern approaches, the use of techniques and tools and the elimination / minimization of losses in the process, brings a strong adherence to the principles of the philosophy of Lean Production System (PALUCHA, 2012).

The main appearance of the Lean Production system happened at the end of World War II, when the Japanese industry had to rethink their production model, appearing then the Toyota Production System (TPS), which due to the lack of productive resources, sought to produce lowest possible cost, especially fighting waste (OHNO, 1988).

The term Lean Production was set in the late 1980s in a research project at the Massachusetts Institute of Technology (MIT), who studied the global automotive industry, with the main focus on the Japanese model of Toyota, aiming to map best practices industry, through interviews with employees, union and government officials. The Lean Production System's philosophy identifying and minimizing or phasing out of waste sources, based on five fundamental principles: the definition of (i) value from the view of the customer and their needs, and then determined the necessary activities to offer the product to the customer at the lowest level waste through the definition of (ii) the value chain. Search is then manufacturing the product using a (iii) continuous flow; which is triggered only when the client makes the request. That is, using a (iv) Pull Production. From these four principles and the use of continuous improvement (kaizen) or radical improvements (kaikaku) is reached the fifth $(v)$ fundamental principle that is the perfection of the system (CALARGE; PEREIRA; SATOLO; DIAZ, 2012). These waste minimization or elimination (Muda in Japanese) are crucial for companies to optimize their activities and to eliminate times and processes that do not add value and are classified into 
DOI: 10.14807/ijmp.v8i1.596

seven types, namely: overproduction, waiting, transportation, motion, over processing, rework and inventory (VINODH; DEVADASAN; VIMAL; KUMAR, 2013).

When reviewing the implementation of Lean Production system in enterprises, it is noted that it can use various techniques and tools, which should take place in a coordinated and structured way (PETTERSEN, 2009; HUNTER, 2004) and assist in this process of minimization and / or elimination of waste, bringing results for the organization as reducing lead times, reduced costs, improved quality and increased productivity, making them agile and more competitive (WALTER; TUBINO, 2004; SAURIN; RIBEIRO; MARODING, 2010). Thus, the techniques and tools are a great help in improving a product or process in various kinds of organizations (FELD, 2001).

Within this context, there is a strong synergy between the World Class Manufacturing approach (WCM) to achieve competitiveness with global levels recommended by the great performance and reduce waste, and that can be implemented through the use of Lean philosophy, and the techniques and tools that support this system.

\section{RESEARCH METHOD}

This research can be considered theoretical because it was developed with bibliographical sources of information gathered through the metasearch portal of CAPES journals along the bases of the Production Engineering and Human and Social Sciences. In these bases were found 24 search sources, among which are cited as an example: Academic Search Premier - ASP (EBSCO), Cambridge Journals Online, Emerald Insight (Emerald), OECD iLibrary, Oxford Journals (Oxford University Press), SAGE Journals online, SciELO.org, ScienceDirect (Elsevier), SpringerLink, Wiley online Library, and others. These data were needed for the construction of bibliometric indicators of scientific production. However, this study is also an applied research, possessing quantitative and qualitative aspects (NEUMAN, 2009).

This research may also, as your goal, be classified as methodologically descriptive because in the search for information and characteristics of the particular subject seeking to know the factors involved, the objectives outlined, and the targeting of studies (MONSEN; HORN, 2007). 
The technique employed to conduct the analysis of publications in this study is bibliometric. This type of survey is one of the methods developed for the systematic review of the literature on a subject or more proposed, having been worked by the Belgian Paul Otlet, which generated over a new field for the measurement of all aspects relating to the publication, reading books and documents, and thus has a characteristic of being methodical, transparent and replicable (ROUSSEAU, 2014; COOK; MULROW; HAYNES, 1997).

A literature review allows to assess with complete accuracy and reliability surveys conducted among specific topics, mapping where papers are published and allowing the researcher generates existing knowledge summaries of the results (CONFORTO; AMARAL; SILVA, 2012).

This research adopted the methodology created by Levy and Ellis (LEVY; ELLIS, 2006), (see Figure 1) which shows a SLR through a process consists of three steps that meet the criteria of this study. However, some modifications and adjustments were needed to comply with the standards defined herein to be achieved, which also reinforce and create the foundation for responding to problems and thus remain the goal.

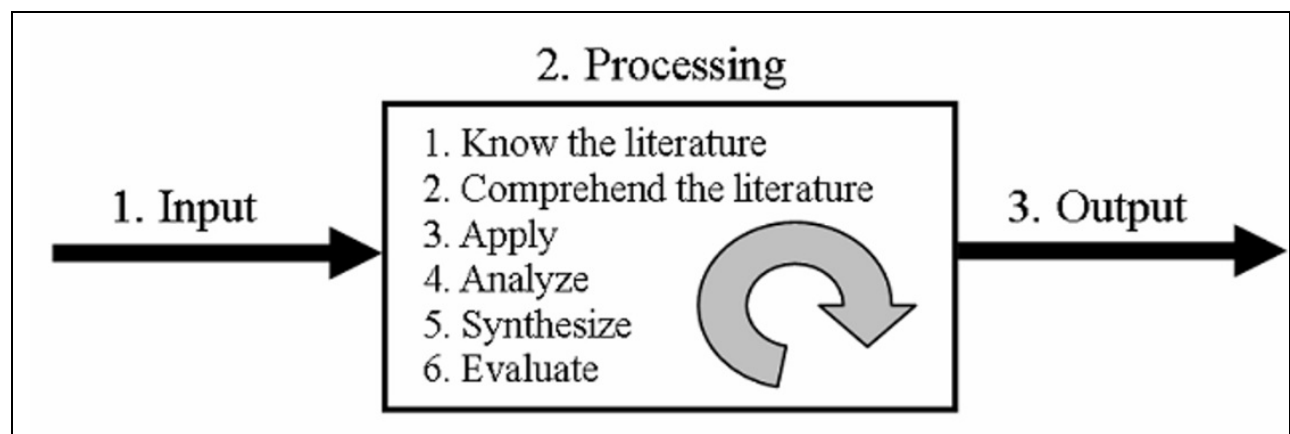

Figure 1. The three steps to conduct a Systematic Literature Review Source: Levy and Ellis (2006)

The process as described, is divided into three stages, where the second stage is the highest concentration of business (LEVY; ELLIS, 2006):

Step 1: Input - its main point is to define the issue proposed connecting all the facts and the objective of which must be very well aligned so that there is clarity and are feasible (CRESWELL, 2013). Above all, here are initiated primary searches on pre-identified databases and stations as collection points, among so you need full attention and rigor in the collection, since this data will become a search of the database (CONFORTO; AMARAL; SILVA, 2012). For this study we performed a time 
DOI: 10.14807/ijmp.v8i1.596

frame in the corresponding period of the last five years (2010 to 2015), where this way it was possible to raise a current database, with demonstration of the latest articles published.

Step 2: Processing - Concentrate the six data processing stages, which are the most important, being comprised as follows:

1st. Stage - To know the literature: identify publications and separate them based on goals;

2nd. Stage - Comprehend the literature: the detailing of information is essential to obtain and interpret what the authors of the research aimed and performed in their studies;

3rd. Stage - Apply: make revisions to search for possible errors in understanding and extracting the necessary parts to compose the survey. As a modification to this research was adopted string searches to refine again the publications of the base taken the first step. In that sense it is necessary to test the combinations adopting the words to the specificity sought thereby to can highlight the importance of carrying out a database for each survey (CONFORTO; AMARAL; SILVA 2012).

4th. Stage - Analyze: is understood in carrying out an analysis of the results to identify what factors include the research objectives through filters, which can perhaps incompatible delete reference to the purpose of the study, which began in the third stage;

5th. Stage - Synthesize: consists of assembling or creating clearly ways to expose the results. Among the ways: charts, tables, images can be built in helping to improve the outlook. From now on, this research was used for the assembly of the social networking Ucinet $\AA$ software that interconnects with the NetDraw $®$, and the word cloud by Wordle ${ }^{\circledR}$;

6th. Stage - Evaluate: describe the results achieved through the analysis and compilation of data, and by the end, to answer the problems found and make considerations about the whole study developed.

Step 3: Output - It is connected with the output of the whole process conducted where it can be disposed in the assessment base built for the research, 
DOI: 10.14807/ijmp.v8i1.596

which in the process of remaking Step 2 as many times as necessary can be excluded by checking and finding that really. It does not belong to adopted people (LEVY; ELLIS, 2006).

A set of the desired information search strategies constituted by words or phrases applied with Boolean operators - which consist of informing the metasearch how to combine the necessary terms. Although the use of signs that can be closed is an expression, and separate the terms in cells (SCHNEIDER; EVANS, 2012). It used the Boolean operators AND and OR, as well as quotes in the truncation of words by objectified search. The AND function is to narrow the search by combining the terms making the intersection of joint research. Already the OR operator is the grouping of terms, expanding research, since many words have leads. The quotation marks have the function to search for exact grouping of words (BARKER; BARKER, 2013).

This way, for raising this study, the search strings were rethought so that the derivatives of words were also found being applied in isolation and later the crossing of the following: (i) "lean production" OR "lean manufacturing"; (ii) "world class manufacturing" OR "world-class" OR "word-class manufacturing"; (iii) "lean production" OR "lean manufacturing" AND "world class manufacturing" OR "worldclass" OR "word-class manufacturing".

In this light, better elucidated in Figure 2, were found at the intersection of terms 98 publications where to apply the second stage adopted the methodological model has resulted in the delineation of 42 (AL-BAIK; MILLER,2014; ZULKIFFLI, 2010).

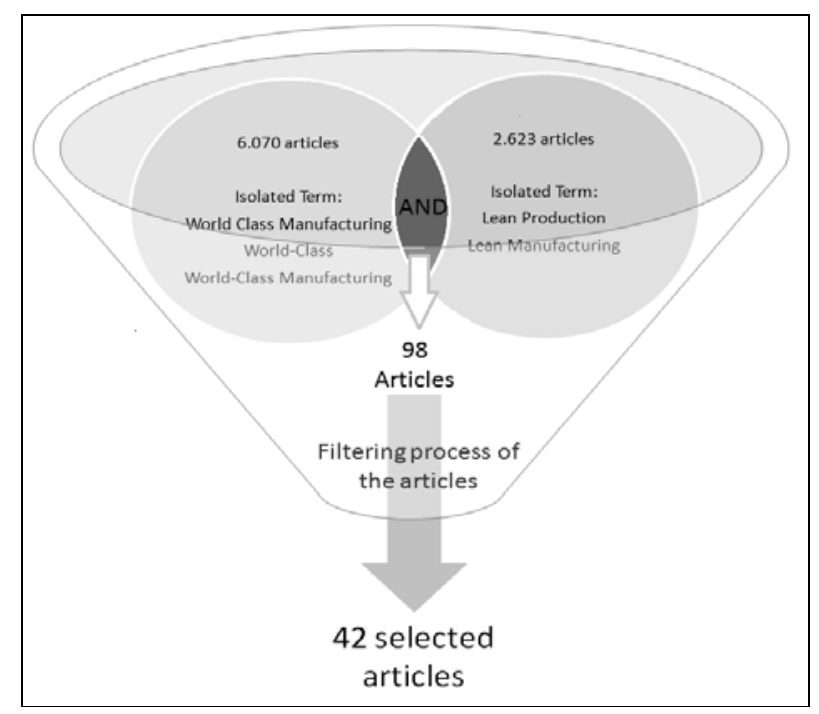

Figure 2: Results of search strings. 


\section{RESULTS}

As noted in section 3, 42 articles that address the research themes were identified. Table 1 lists these articles. The column "Article Number" stands out as the basis for locating the articles in the figures related to the analysis of social networks. The authors, year of publication and the published periodical are presented along with this numbering.

Table 1: List of selected articles considered in current study

\begin{tabular}{|c|c|c|c|}
\hline $\begin{array}{l}\text { Article } \\
\text { Number }\end{array}$ & Authors & Year & Periodical \\
\hline 1 & GURUMURTHY; KODALI & 2011 & $\begin{array}{l}\text { Journal of Manufacturing Technology } \\
\text { Management }\end{array}$ \\
\hline 2 & DEMETER; MATYUSZ & 2011 & International Journal of Production Economics \\
\hline 3 & HEDELING; JACKSON & 2011 & $\begin{array}{l}\text { Journal of Manufacturing Technology } \\
\text { Management }\end{array}$ \\
\hline 4 & TOHIDI & 2012 & Advances in environmental biology \\
\hline 5 & $\begin{array}{l}\text { FORRESTER; SHIMIZU; } \\
\text { SORIANO-MEIER; GARZA- } \\
\text { REYES; BASSO }\end{array}$ & 2010 & $\begin{array}{l}\text { Journal of Manufacturing Technology } \\
\text { Management }\end{array}$ \\
\hline 6 & MEYBODI & 2013 & Advances in Competitiveness Research \\
\hline 7 & PONG; MITCHELL & 2012 & The British Accounting Review \\
\hline 8 & $\begin{array}{l}\text { TANCO; SANTOS; RODRIGUEZ; } \\
\text { REICH }\end{array}$ & 2013 & $\begin{array}{l}\text { International Journal of Advanced } \\
\text { Manufacturing Technology }\end{array}$ \\
\hline 9 & $\begin{array}{l}\text { ANGELIS; CONTI; COOPER; } \\
\text { GILL }\end{array}$ & 2011 & $\begin{array}{l}\text { Journal of Manufacturing Technology } \\
\text { Management }\end{array}$ \\
\hline 10 & $\begin{array}{l}\text { VINODH; ARVIND; } \\
\text { SOMANAATHAN }\end{array}$ & 2010 & Journal of Manufacturing Systems \\
\hline 11 & CHOWDARY; GEORGE & 2011 & $\begin{array}{l}\text { Journal of Manufacturing Technology } \\
\text { Management }\end{array}$ \\
\hline 12 & BOZICKOVIC; MARIC & 2013 & DAAAM international scientific book \\
\hline 13 & $\begin{array}{l}\text { RAHMAN; } \\
\text { LAOSIRIHONGTHONG; SOHAL }\end{array}$ & 2010 & $\begin{array}{l}\text { Journal of Manufacturing Technology } \\
\text { Management }\end{array}$ \\
\hline 14 & ALONY; CAPUTI; COLTMAN & 2011 & $\begin{array}{l}\text { Issues in informing science \& information } \\
\text { technology }\end{array}$ \\
\hline 15 & WANG; MING; KONG; LI; WANG & 2011 & Forest Products Journal \\
\hline 16 & ESAN; KHAN ; QI; NAYLOR & 2013 & $\begin{array}{l}\text { Journal of Manufacturing Technology } \\
\text { Management }\end{array}$ \\
\hline 17 & MONGE; CRUZ; LOPEZ & 2013 & Informacion Tecnologica \\
\hline 18 & FURLAN; DAL PONT; VINELLI & 2011 & International Journal of Production Economics \\
\hline 19 & PAIVA & 2010 & International Journal of Production Economics \\
\hline 20 & WIENGARTEN; PAGELL & 2012 & International Journal of Production Economics \\
\hline 21 & $\begin{array}{l}\text { NAOR; LINDERMAN; } \\
\text { SCHROEDER }\end{array}$ & 2010 & Journal of Operations Management \\
\hline 22 & KISPERSKA-MORON; DE HAAN & 2011 & International Journal of Production Economics \\
\hline 23 & BRANDT; THUN & 2010 & World Development \\
\hline 24 & $\begin{array}{l}\text { TYAGI; CHOUDHARY; CAI; } \\
\text { YANG }\end{array}$ & 2015 & International Journal of Production Economics \\
\hline
\end{tabular}




\section{INDEPENDENT JOURNAL OF MANAGEMENT \& PRODUCTION (IJM\&P)}

http://www.ijmp.jor.br

v. 8, n. 2, April - June 2017

ISSN: 2236-269X

DOI: 10.14807/ijmp.v8i1.596

\begin{tabular}{|c|l|l|l|}
25 & $\begin{array}{l}\text { BORTOLOTTI; BOSCARI; } \\
\text { DANESE }\end{array}$ & 2015 & International Journal of Production Economics \\
\hline 26 & $\begin{array}{l}\text { VINODH; DEVADASAN; VIMAL; } \\
\text { KUMAR }\end{array}$ & 2013 & $\begin{array}{l}\text { Journal of Manufacturing Technology } \\
\text { Management }\end{array}$ \\
\hline 27 & SHAN; WANG; XIN; BI & 2013 & International Journal of Production Economics \\
\hline 28 & BORADE; BANSOD & 2010 & $\begin{array}{l}\text { Journal of Manufacturing Technology } \\
\text { Management }\end{array}$ \\
\hline 29 & THAKKAR; KANDA; DESHMUKH & 2012 & $\begin{array}{l}\text { Journal of Manufacturing Technology } \\
\text { Management }\end{array}$ \\
\hline 30 & $\begin{array}{l}\text { VIEIRA JUNIOR; LUCATO; } \\
\text { VANALLE }\end{array}$ & 2014 & $\begin{array}{l}\text { Journal of Manufacturing Technology } \\
\text { Management }\end{array}$ \\
\hline 31 & $\begin{array}{l}\text { O'SULLIVAN; ANDREONI; } \\
\text { LOPEZ-GÓMEZ; GREGORY }\end{array}$ & 2010 & Oxford Review Of Economic Policy \\
\hline 32 & GARBIE & 2011 & Journal of Service Science and Management \\
\hline 33 & $\begin{array}{l}\text { PENG; VERGHESE; SHAH; } \\
\text { SCHROEDER }\end{array}$ & 2013 & Journal of Supply Chain Management \\
\hline 34 & $\begin{array}{l}\text { BACCHETTI, ANDREA; } \\
\text { SACCANI, NICOLA }\end{array}$ & 2012 & Omega \\
\hline 35 & SHAHIN; ATTARPOUR & 2011 & Modern Applied Science \\
\hline 36 & AL-BAIK; MILLER & 2014 & Empirical Software Engineering \\
\hline 37 & ZULKIFFLI & 2010 & $\begin{array}{l}\text { International Journal of Business and } \\
\text { Management Science }\end{array}$ \\
\hline 38 & MEYBODI & 2010 & Advances in Competitiveness Research \\
\hline 39 & KRISTENSEN; ISRAELSEN & 2014 & Management Accounting Research \\
\hline 40 & CHOWDHURY & 2014 & Business Horizons \\
\hline 41 & GONZALEZ; MARTINS & 2014 & Journal of Knowledge Management \\
\hline 42 & CLOSS; SPEIER; MEACHAM & 2011 & Journal of the Academy of Marketing Science \\
\hline & & & \\
\hline
\end{tabular}

A starting point to highlight is the variety of authors with publications throughout the period investigated. It can be observed that of the 42 publications in only four occur the repetition of authors, as in the case of Meybody $(2010 ; 2013)$ and Vinodh et al. (2010) and Vinodh et al. (2013). This aspect demonstrates that the subject is still in a phase of exploration, and there are no researchers in the current period of research and among the bases researched, which stand out in terms of number of publications.

This fact does not occur when verifying the journals adopted by the researchers when presenting the society their researches. The 42 publications identified are published in 25 journals, of which two (Journal of Manufacturing Technology Management and International Journal of Production Economics) stand out by concentrating $45.2 \%$ of the publications.

In Figure 3 the quantitative representation of publications over the years was developed. Of these papers, $24 \%$ are published in 2011, showing that this way there was a drop in production over this period by the year 2015 , as seen in Figure 3 . This 
DOI: 10.14807/ijmp.v8i1.596

can be caused by a variety of reasons, from the researchers' lack of interest in relating the issues to working on administrative strategies in isolation. It is also difficult to identify theoretical studies that indicate how theoretical convergence occurs between the two administrative strategies, and that in some articles that report practice in the business environment highlight the positive results achieved, but do not outline the way to tread for success.

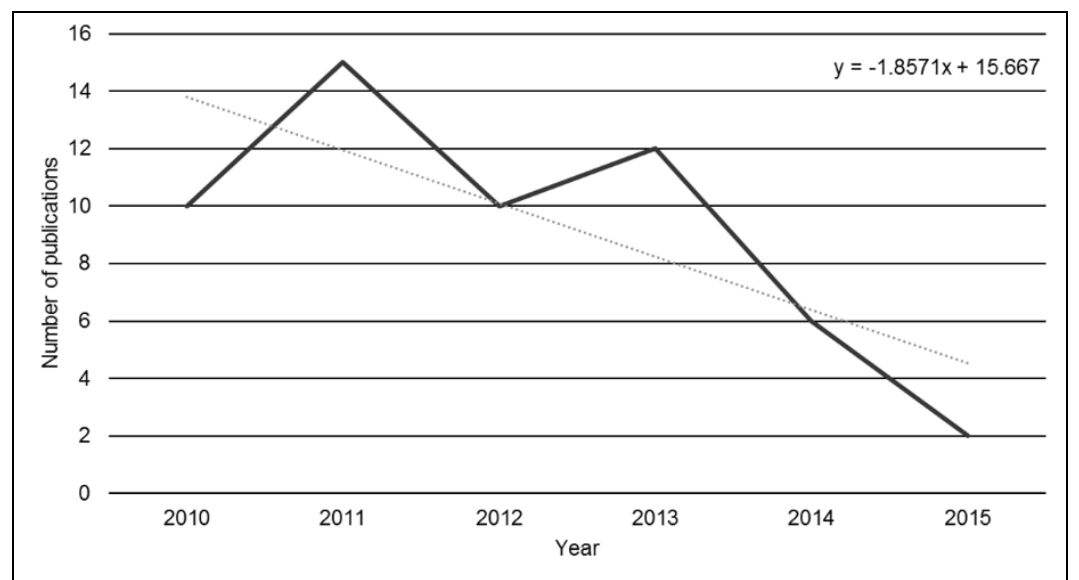

Figure 3: Number of publications in the year's survey.

Another analysis performed with regard to methodological questions of the research, which are divided into four aspects:

(i) objective of the research that can be understood in three ways: (a) descriptive, when the process consists in the investigation, interpretation of historical facts to get understanding; (b) exploratory, when it is necessary to create a specific function to get results and; (c) explicative, in which it talks about these facts for a justification from a different point of view or to be the opposite, or even the need for a different point on the subject.

(ii) The second aspect is related to how the research (ii) approach: characterized as (a) qualitative, when there is a focus on interpreting rather quantifying, orientation for the process and not for the result, preoccupation with context, in the sense that people's behavior and the situation bind closely in the formation of experience and; (b) quantitative, using structured procedures, formal data collection instruments under control conditions. 
(iii) The third refers to the (iii) types of research, It was identified the predominance of three: (a) case study, of empirical investigating a particular phenomenon, usually contemporary, within a real life context, when the boundaries between the phenomenon and the context in which it inserts are not clearly defined; (b) survey, comprising a data collection on a significant sample about a problem to be studied for, then by quantitative analysis, obtain them conclusions corresponding to the data collected and; (c) conceptual, which is connected to the study of existing theories and explanations of the concepts and techniques used.

(iv) Ultimately, the latter deals with the (iv) analysis tools and data collections that understand: (a) documentary, which is employed by the survey documents that characterize the data and employment relationships with research and; (b) form, which aims at collecting and analyzing data through statistical procedures, it is their preconceived investigations by relationships of ideas (YIN, 2010; MIGUEL, 2011; CASSELL; SYMON, 1994; MARCONI; LAKATOS, 2002).

The Figure 4 summarizes this analysis and indicates that research using mostly of an exploratory methodology with a qualitative approach, it is developed by case studies and application forms.

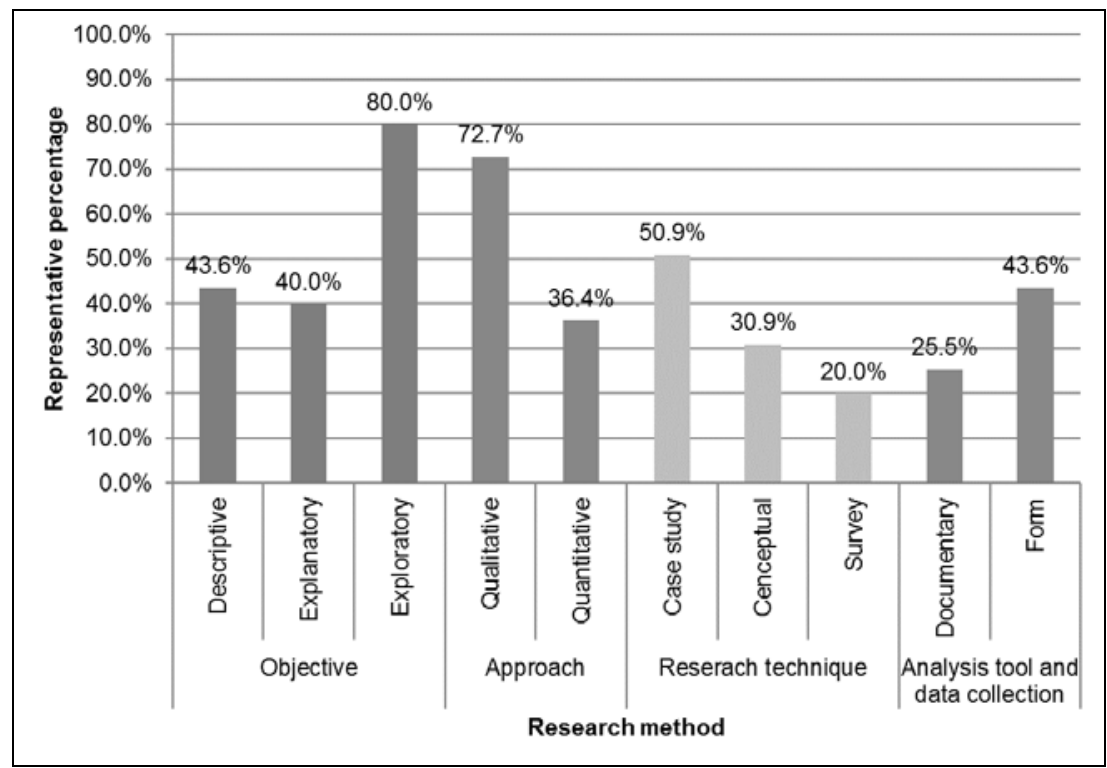

Figure 4: Percentage of employees questions about the purpose, approach, techniques, and methods for data collection. 
This aspect can be explained by the term Lean Production concept is inherited from the Toyota Production System, which was born in the automotive sector (YAMASHINA, 2000). Large companies with high power and production technology that use such methods becoming search target for the development of studies and developments of theory. However, as is the quantitative approach is related to several different attempts at achieving measure processes in respect to construction of algorithms, or software.

This shows that the scientific productions inherent in the issues under study are in traditional sectors of transformation of industrial goods, and few studies conducted by the agro-industrial sector and services.

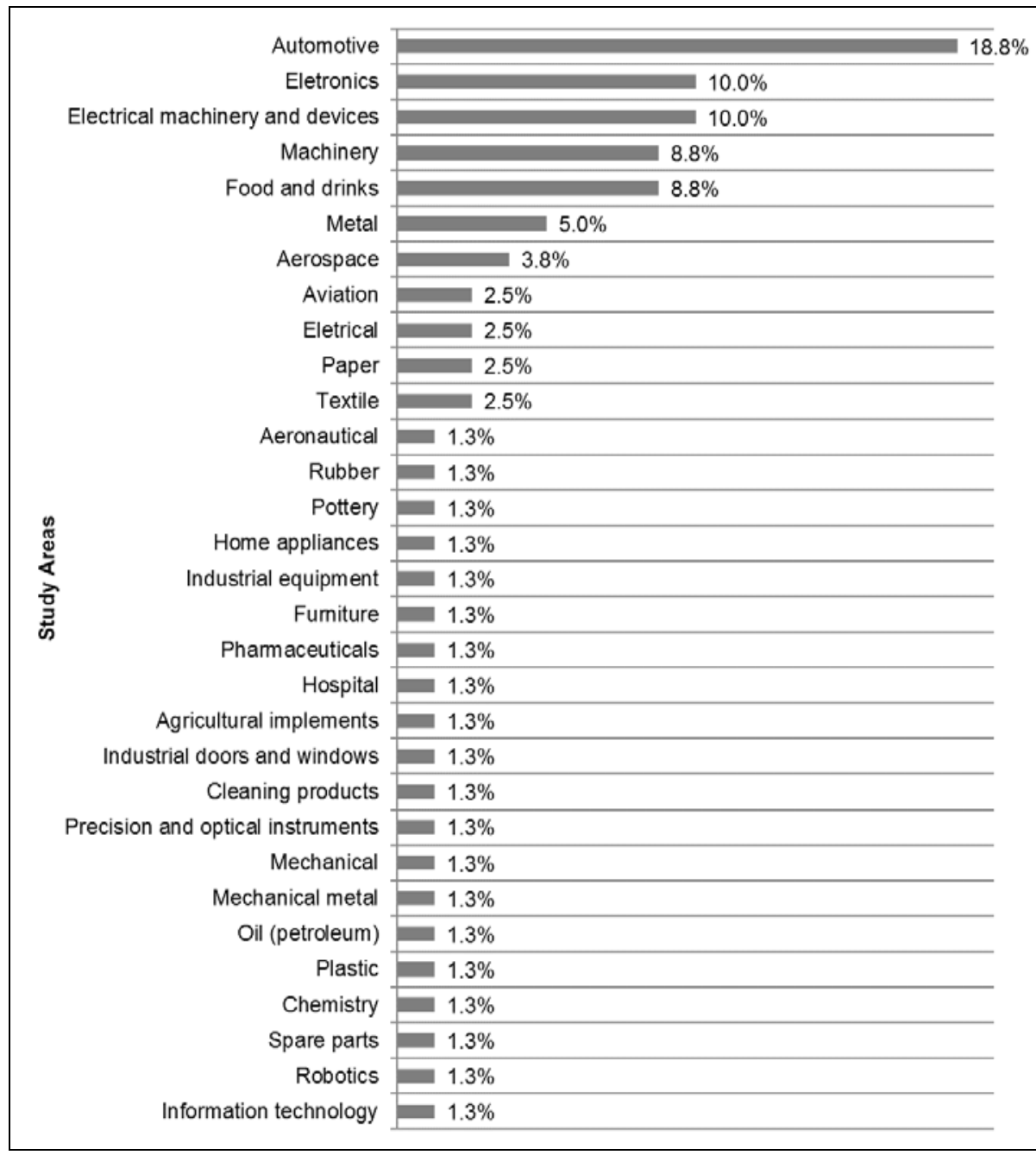

Figure 5: Percentage of concentration of research sectors.

The publications on the searched subjects have been conducted by researchers from different countries, highlighted in Figure 6. We identified 24 countries published in the period surveyed, involving 145 researchers. The United 
DOI: 10.14807/ijmp.v8i1.596

States are the largest producer of research on the issues and have the majority of researchers, being 41 in total. The UK and India stand out with 22 and 15 researchers, respectively, followed by Brazil, Canada and China with 8 researchers each. These six main generators of knowledge countries concentrate $70 \%$ of the publications.

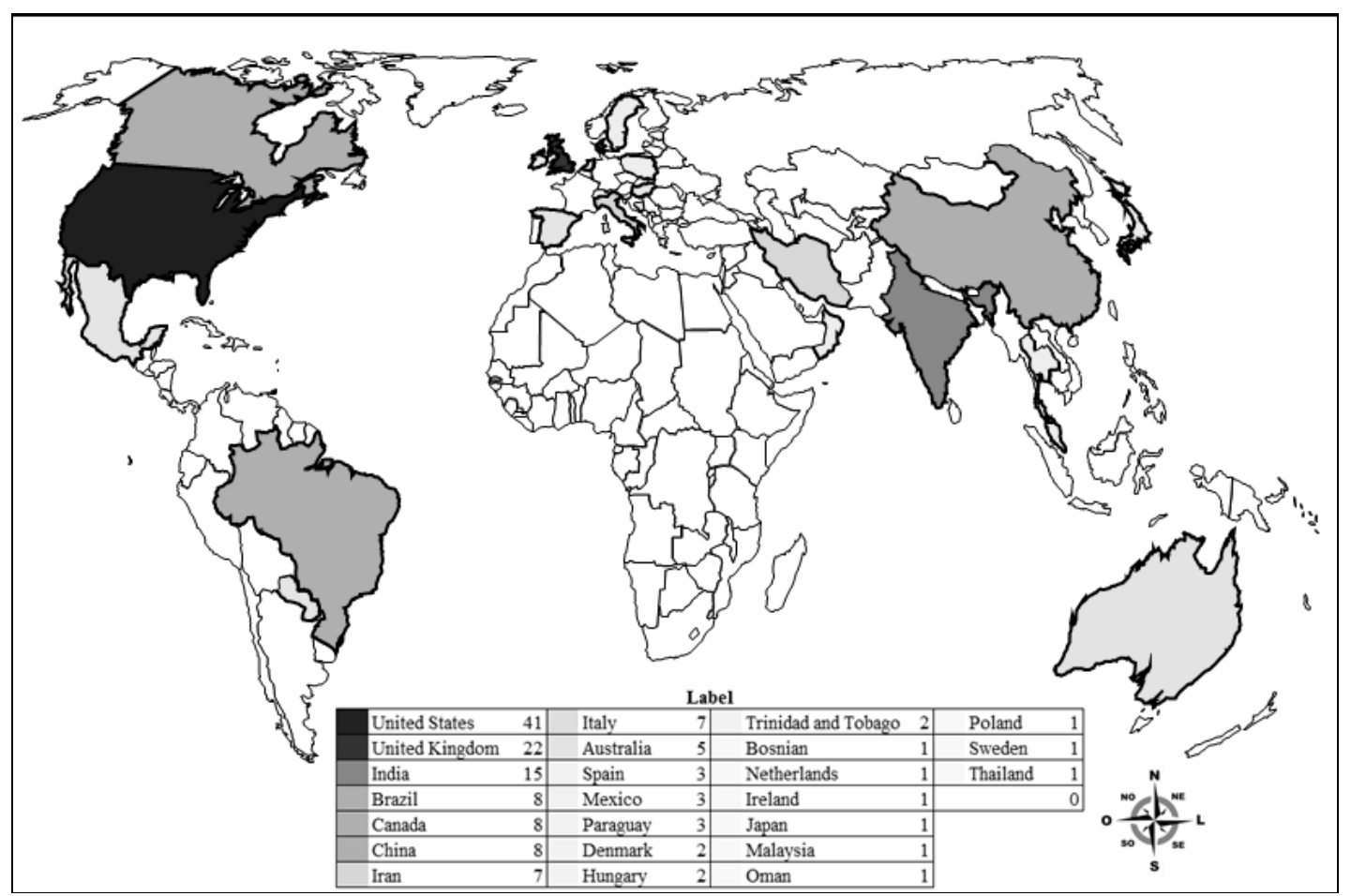

Figure 6: Number of researchers by countries.

The Figure 7 projects the social network of identified articles and their correlation with the keywords. This construction allows display as a set of actors that have correlation with each other, in which can be of different types present different contents as well as different structural properties (WORRELL; WASKO; JOHNSTON, 2013). 


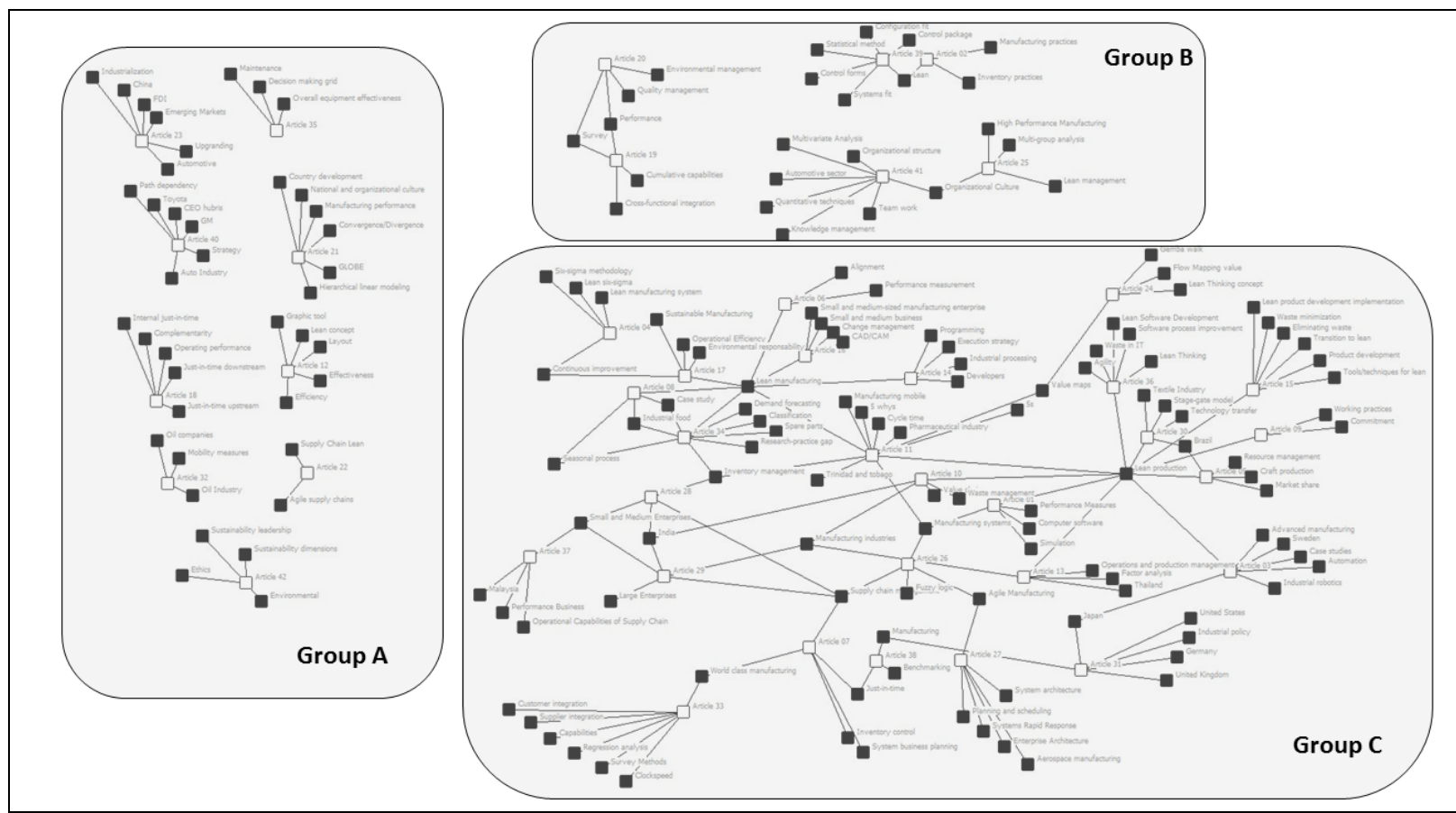

Figure 7: Number of network publications in the years survey.

In analyzing social networks, the most important aspect is to identify the most cohesive subgroups of actors (SCOTT, 2012). It is noted that this network of actors presents three main groups.

- Group A - Made up of 9 articles (BOZICKOVIC; MARIC,2013; BRANDT; THUN, 2010; CHOWDHURY,2014; CLOSS; SPEIER; MEACHAM; MEACHAM, 2011; FURLAN; DAL PONT; VINELLI, 2011; KISPERSKAMORON; HAAN, 2011; NAOR; LINDERMAN; SCHROEDER, 2010; GARBIE, 2011; SHAHIN; ATTARPOUR, 2011), which are isolated and address issues isolated from other works identified.

- Group B - has 6 articles divided into two small groups of common themes, formed by Articles (DEMETER; MATYUSZ, 2011; KRISTENSEN; ISRAELSEN, 2014; PAIVA, 2010; WIENGARTEN; PAGELL, 2012; BORTOLOTTI; BOSCARI; DANESE, 2015; GONZALEZ; MARTINS, 2014).

- Group C - Group of greater concentration of research topics, formed by the 27 remaining articles, and that the main focus of relations issues. This network is displayed most prominently in Figure 8. 


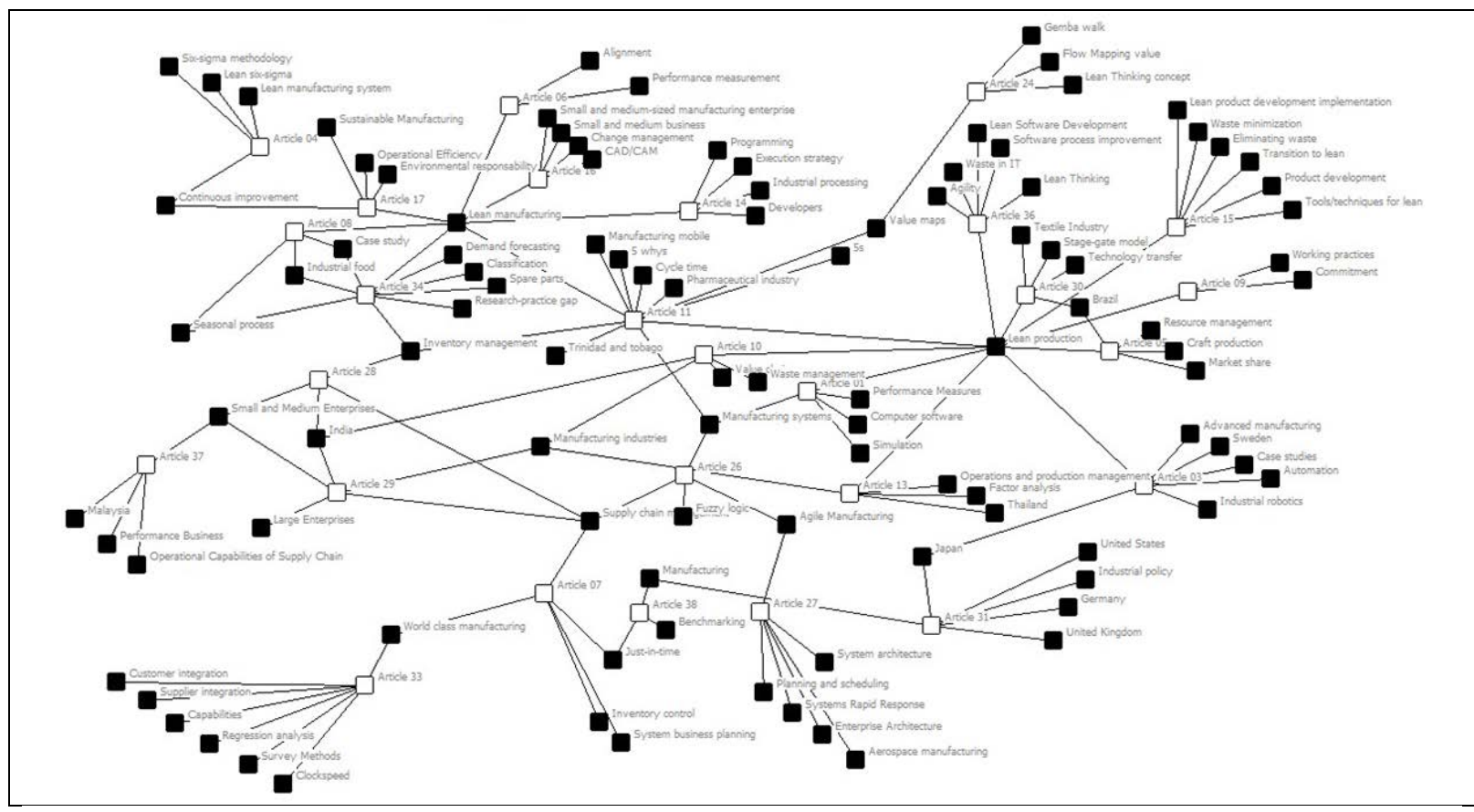

Figure 8: Group C network actors.

The Figure 8 details a network feature to be in training, and in some decentralized points where we have a low connection with other themes, as in articles on the outskirts of the figure. However, at times it presents itself as a distributed network, such as the articles located in the central part of the figure with strong links between keywords and articles (SCOTT, 2012). This shows that the research WCM and Lean Production is still at an early stage to mature, where the themes are initiating greater interaction, demonstrating that researchers can already go on the association themes.

This stage of low maturity refers to the classification of Grandori and Soda (1995) for a Social Asymmetric Network, in other words, a configuration not governed by formal contracts in relationships, and asymmetry between the surveyed subjects (higher prevalence of certain themes, though not occur extreme asymmetries). This classification is quite consistent, and predictable, since the opposing themes have not yet established their areas of concentration and performance, or in the terminology of Flingstein (1996) their organizational fields.

The World Class Manufacturing keyword, which was one of the search terms, presented in a single connection and is used for only two publications as keywords. Already the word Lean Production is more binding and strength. A possible understanding of this context can be understood because metasearch Portal CAPES 
DOI: 10.14807/ijmp.v8i1.596

use search across the full text when allocated a word or term, being considered all the elements such as title, abstract, keywords, and all remainder.

Still referring to social network analysis, is strengthened by the word cloud job in Figure 9, the power to simulate the amount of repetition that keywords present when allocated in order to achieve tabular. This cloud shows that there is a concentration of words Lean Production, small and medium enterprises, inventory management, lean manufacturing, supply chain management, manufacturing systems, and India. Note that the term World Class Manufacturing presents little attention within the research, confirming that while research on the subject are conducted, there is a low citation index compared theme Lean Production.

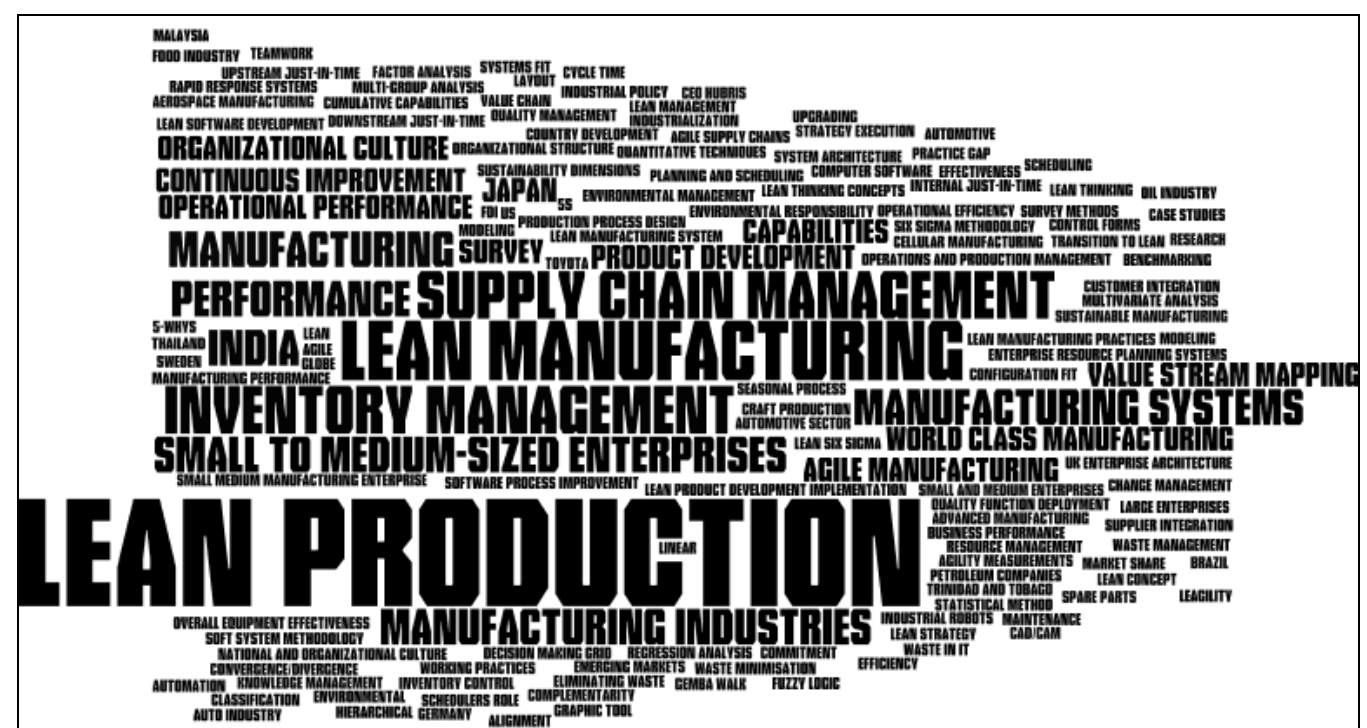

Figure 9: Word cloud of the keywords you incorporate in publications (2010-2015)

\section{CONCLUSIONS}

This study is proposing to conduct a bibliometric research publication on the topics Lean Production and World Class Manufacturing. The metasearch Portal CAPES that joins various high reference scientific bases and reliability was used. They identified 42 publications that addressed the issues in the last five years and this goal has identified important aspects about the studies conducted.

As for the identified results, we note that during the years 2010 and 2011 more researches were developed and that by the year 2014 these studies were in decline. Even until the first half of 2015 were found within the metasearch only two publications. It is assumed, which is slow the studies of investigation time, and also 
DOI: 10.14807/ijmp.v8i1.596

that each journal has dates for publication of their volumes, thus changing the result to the current year's end.

It was found that although distributed to publications, research has their researchers as a country of origin the United States showing greater contribution to the development of themes. However, denoted Japan, the country where it was inherited one of the subjects, with only one participant researcher will be shown.

Regarding the study of the network of actors, note that this is presented in an early stage to maturity, appearing for the most part as decentralized, but with actions to become distributed in some subjects, indicating that researchers. They begin to glimpse the association between topics.

\section{REFERENCES}

AL-BAIK, O.; MILLER, J. (2014) Waste identification and elimination in information technology organizations, Empirical Software Engineering, v. 19, n. 6, p. 20192061.

ALONY, I.; CAPUTI, P.; COLTMAN, T. (2011) Informing Implementers of Lean Strategy in Process Industries-The Central Role of Schedulers, Issues in Informing Science \& Information Technology, v. 8, p. 335.

ANGELIS J.; CONTI, R.; COOPER, C.; GILL, C. (2011) Building a high-commitment lean culture, Journal of Manufacturing Technology Management, v. 22, n. 5, p. 569-586.

ASKARI, A. (2004) An integrated strategic model to achieve world class manufacturing (ISM-WCM) (Doctoral Dissertation), University of Science \& Technology, Tehran, Iran.

BACCHETTI, A.; SACCANI, N. (2012) Spare parts classification and demand forecasting for stock control: Investigating the gap between research and practice, Omega, v. 40, n. 6, p. 722-737.

BARKER, D. I.; BARKER, M. (2013) Internet research illustrated, $7^{\text {th }}$, Stanford, Cengage Learning.

BORADE, A. B.; BANSOD, S. V. (2010), Study of vendor-managed inventory practices in Indian industries. Journal of Manufacturing Technology Management, v. 21, n. 8, p. 1013-1038.

BORGES, R. C.; OLIVEIRA, E. H.; OLIVEIRA, A. S.; (2013) Study the implementation of the pillar quality control of world class manufacturing methodology (WCM) in a automotive company in the south of Minas Gerais (in portuguese), in: Proceedings of the Simpósio de Administração da Produção, Logística e Operações Internacionais, São Paulo: FGV, Brazil, p. 1-17.

BORTOLOTTI, T.; BOSCARI, S.; DANESE, P. (2015) Successful lean implementation: Organizational culture and soft lean practices, International Journal of Production Economics, v. 160, p. 182-201. 
BOZICKOVIC, R.; MARIC, B. (2013) Lean concept--a challenge to managers for the better future of the company, DAAAM International Scientific Book, v. 1, n. 1, p. 491-510.

BRANDT, L.; THUN, E. (2010) Thun, The fight for the middle: upgrading, competition, and industrial development in China. World Development, v. 38, n. 11, p. $1555-1574$.

BUCHANAN D.; HUCZYNSKI, A. (2004) Organizational behavior, 5 ed., Harlow, Prentice-Hall.

BURCHER, P.; STEVENS, K. (1996) Measuring up to World Class Manufacturing, Aston Business School.

CALARGE, F. A.; PEREIRA, F. H.; SATOLO, E. G.; DIAZ, E. C. (2012) Evaluation of Lean Production System by using SAE J4000 standard: case study in Brazilian and Spanish automotive component manufacturing organizations, African Journal of Business Management, v. 6, n. 49, p. 11839-50.

CASSELL, C.; SYMON, G. (1994) Qualitative methods in organizational research, London, Sage Publications.

CHIARINI, A.; VAGNONI, E. (2014) World-class manufacturing by Fiat. Comparison with Toyota Production System from a strategic management, management accounting, operations management and performance measurement dimension, International Journal of Production Research, v. 53 n. 2, p. 590-606.

CHOWDARY, B. V.; GEORGE, D. (2011) Improvement of manufacturing operations at a pharmaceutical company: a lean manufacturing approach. Journal of Manufacturing Technology Management, v. 23, n. 1, p. 56-75.

CHOWDHURY, S. D. (2014) Strategic roads that diverge or converge: GM and Toyota in the battle for the top, Business Horizons, v. 57, n. 1, p. 127-136.

CLOSS, D. J.; SPEIER C.; MEACHAM, N. M. (2011) Sustainability to support endto-end value chains: the role of supply chain management. Journal of the Academy of Marketing Science, v. 39, n. 1, p. 101-116.

CONFORTO, E. C.; AMARAL D. C.; SILVA S. L. (2012) Roadmap for systematic literature review: application in product development and project management (in portuguese), in: Proceedings of the Congresso Brasileiro de Gestão de Desenvolvimento de Produto-CBGDP, Porto Alegre, Brazil, p. 1-12.

COOPER, H. (1998) Synthesizing Research, Thousand Oaks, Sage.

COOK, D. J; MULROW, C. D.; HAYNES, R. B. (1997) Systematic reviews: synthesis of best evidence for clinical decisions. Annals of Internal Medicine, v. 126, n. 5, p. 376-380.

CRESWELL, J. W. (2013) Research design: qualitative, quantitative, and mixed methods approaches, Thousand Oaks, Sage Publications.

DEMETER, K.; MATYUSZ, Z. (2011) The impact of lean practices on inventory turnover. International Journal of Production Economics, v. 133, n. 1, p. 154163.

EID, R. (2009), Factors affecting the success of world class manufacturing implementation in less developed countries. Journal of Manufacturing Technology Management, v. 20, n. 7, p. 989-1008. 
EDOSOMWAN, J. A. (1996) Strategies for World-Class Manufacturing: the quality observer. Management Science and Engineering, v. 6, n. 3, p. 6-9.

ESAN, A. O.; KHAN, M. K.; QI, H. S.; NAYLOR, C. (2013) Integrated manufacturing strategy for deployment of CADCAM methodology in a SMME, Journal of Manufacturing Technology Management, v. 24, n. 2, p. 257-273.

ESCRIG-TENA, A. (2004) TQM as a competitive factor: a theoretical and empirical analysis, International Journal of Quality \& Reliability Management, v. 21, n. 6, p. 612-37.

FARISH, M. S. (1995) Strategies for World Class Products. England. Gower: Hampshire.

FELD, W. M. (2001) Lean manufacturing: tools, techniques, and how to use them. New York, CRC Press.

FLIGSTEIN, N. (1996) Markets as politics: a political-cultural approach to market institutions, American Sociological Review, v. 61, n. 4, p. 656-673.

FORRESTER, P. L.; SHIMIZU, U. K.; SORIANO-MEIER, H.; GARZA-REYES, J. A.; BASSO, L. F. C. (2010) Lean production, market share and value creation in the agricultural machinery sector in Brazil, Journal of Manufacturing Technology Management, v. 21, n. 7, p. 853-871.

FURLAN, A.; DAL PONT, G.; VINELLI, A. (2011) On the complementarity between internal and external just-in-time bundles to build and sustain high performance manufacturing. International Journal of Production Economics, v. 133, n. 2, p. 489-495.

GAJDZIK, B. (2013) World class manufacturing in metallurgical enterprise, Metalurgija, Croatia, v. 52, n. 1, p. 131-134.

GARBIE, I. H. (2011) Implementation of agility concepts into oil industry. Journal of Service Science and Management, v. 4, n. 2, p. 203.

GILGEOUS, V.; GILGEOUS, M. A. (1999) Framework for manufacturing excellence, Integrated Manufacturing Systems, v. 10, p. 33-44.

GOETSCH, D. L.; DAVIS, S. B. (2014) Quality management for organizational excellence, New Jersey, Pearson.

GONZALEZ, R. V. D.; MARTINS, M. F. (2014) Mapping the organizational factors that support knowledge management in the Brazilian automotive industry. Journal of Knowledge Management, v. 18, n. 1, p. 152-176.

GRANDORI, A.; SODA, G. (1995) Inter firm networks: antecedents, mechanism and forms, Organization Studies, v. 16, n. 2, p. 183-214.

GUNASEKARAM, A. (2000) World Class Manufacturing in small and medium enterprises, International Journal of Manufacturing Technology and Management, v. 7, p. 777-789.

GURUMURTHY, A.; KODALI, R. (2011) Design of lean manufacturing systems using value stream mapping with simulation: a case study, Journal of Manufacturing Technology Management, v. 22, n. 4, p. 444-473.

HAYES, R. H.; WHEELWRIGHT S. C. (1984) Restoring our competitive edge: competing through manufacturing, Wiley, New York. 
HEDELIND, M.; JACKSON, M. (2011) How to improve the use of industrial robots in lean manufacturing systems, Journal of Manufacturing Technology Management, v. 22, n. 7, p. 891-905

HOSSEINIE, S. M. S.; SHIRAZI, A. N. M.; ASHLOGHI, A. T.; MEHRAN, M. H. (2012) The combination of soft system and quality function deployment methodologies in the design and development of the comprehensive model world class manufacturing processes. Management Science and Engineering, Canada, v. 6, n. 2 , p. 22-34.

HUNTER, S. L. (2004) Ten Steps to Lean Production. FDM Management, v. 76, n. 5 , p. 20-23.

KISPERSKA-MORON D.; HAAN, J. (2011) Improving supply chain performance to satisfy final customers: "leagile" experiences of a polish distributor, International Journal of Production Economics, v. 133, n. 1, p. 127-134.

KRISTENSEN, T. B.; ISRAELSEN, P. (2014) Performance effects of multiple control forms in a Lean organization: A quantitative case study in a systems fit approach, Management Accounting Research, v. 25, n. 1, p. 45-62.

LEVY, Y.; ELLIS, T. J. (2006) A system approach to conduct an effective literature review in support of information systems research, Informing Science Journal, v. 9, p. 181-212.

MCADAM, R.; HENDERSON, J. (2004), Influencing the future of TQM: internal and external driving factors. International Journal of Quality \& Reliability

Management, v. 21, n. 1, p. 51-57.

MARCONI, M. A.; LAKATOS, E. M. (2002) Técnicas de pesquisa: planejamento e execução de pesquisas, amostragens e técnicas de pesquisas, elaboração, análise e interpretação de dados. $4^{\text {th }}$, São Paulo, Atlas.

MEYBODI M. Z. (2013) Alignment of Strategic Benchmarking Performance Measures: A Lean Manufacturing Perspective, Journal of Competitiveness Studies, v. 21, n. 1/2, p. 14.

MEYBODI, M. Z. (2010) The impact of just-in-time practices on consistency of benchmarking performance measures, Advances in Competitiveness Research, v. 18 , n. $1 / 2$, p. 73.

MONGE C.; CRUZ J.; LÓPEZ F. (2013) Impacto de la manufactura esbelta, manufactura sustentable y mejora continua en la eficiencia operacional y responsabilidad ambiental en México, Información tecnológica, v. 24, n. 4, p. 1532.

MONSEN, E. R.; HORN, L. V. (2007) Research: successful approaches, American Dietetic Association.

MOTWANI, J.; KUMAR, A.; KATHAWALE, Y.; WCM, Y. (1994) Practices of North American Manufacturing Organizations. Journal of Industrial Management \& Data Systems, v. 94 n. 7, p. 18-23.

MIGUEL, P. A. C. (2011) Research methodology in engineering production and operations management, $2^{\text {th }}$ São Paulo, Elsevier.

NAOR, M.; LINDERMAN, K.; SCHROEDER, R. (2010) The globalization of operations in Eastern and Western countries: Unpacking the relationship between 
national and organizational culture and its impact on manufacturing performance, Journal of Operations Management, v. 28, n. 3, p. 194-205.

NEUMAN, W. L. (2009) Social research methods: qualitative and quantitative approaches, $7^{\text {th }}$, New Jersey, Pearson.

NG, K. C.; HUNG, I. W. (2001) A model for global manufacturing excellence, Work Study, v. 50, p. 63-68.

OAKLAND, J. S. (2001) Total Organizational Excellence: achieving World Class Performance, Oxford, Elsevier.

OHNO, T. (1988) Toyota Production System: beyond large scale production, Cambridge, Productivity PR.

O'SULLIVAN, E.; ANDREONI A.; LÓPES-GÓMEZ, C.; GREGORY, M. (2013) What is new in the new industrial policy? A manufacturing systems perspective, Oxford Review of Economic Policy, v. 29 n. 2, p. 432-462.

PAIVA, E. L. (2010) Manufacturing and marketing integration from a cumulative capabilities perspective, International journal of production economics, v. 126, n. 2, p. 379-386.

PALUCHA, K. (2012) World class manufacturing model in production management. Science and Engineering, Poland, v. 58, n. 2, p. 227-234.

PENG, D. X.; VERGHESE, A.; SHAH. R.; SCHROEDER, R. G. (2013) The relationships between external integration and plant improvement and innovation capabilities: The moderation effect of product clock speed, Journal of Supply Chain Management, v. 49, n. 3, p. 3-24.

PETTERSEN, J. (2009) Defining lean production: some conceptual and practical issues, The TQM Journal, v. 21, n. 2, p. 127-142.

PONG, C. K. M.; MITCHELL, F. (2012) Inventory investment \& control: How have UK companies been doing?, The British Accounting Review, v. 44, n. 3, p. 173188.

RAHMAN, S.; LAOSIRIHONGTHONG, T.; SOHAL, A. S. (2010) Impact of lean strategy on operational performance: a study of Thai manufacturing companies. Journal of manufacturing technology management, v. 21, n. 7, p. 839-852.

ROUSSEAU R. (2014), Library science: forgotten founder of bibliometrics. Nature, v. 510, n. 218, p. 12.

SHAHIN, A.; ATTARPOUR, M. R. (2011) Developing decision making grid for maintenance policy making based on estimated range of overall equipment effectiveness, Modern applied science, v. 5, p. 86.

SHAN, S.; WANGA, L.; XINA, T.; BIB, Z. (2013) Developing a rapid response production system for aircraft manufacturing, International Journal of Production Economics, v. 146, n. 1, p. 37-47.

SHARMA, M.; KODALI, R. (2008) Development of a framework for manufacturing excellence, Measuring Business Excellence, v. 12, n. 4, p. 55-60.

SAURIN, T. A.; RIBEIRO, J. L. D.; MARODIN, G. A. Marodin (2010) Identificação de oportunidades de pesquisa a partir de um levantamento da implantação da 
produção enxuta em empresas do Brasil e do exterior (in portuguese), Gestão \& Produção, v. 17, n. 4, p. 829-841.

SCHNEIDER, G. P.; EVANS, J. (2012) New perspectives on the internet: introductory, $9^{\text {th }}$, Stanford, Cengage Learning.

SCHONBERGER, R. J. (1996) World Class Manufacturing: the next decade: building power, strength, and value. New York, Free Press.

SCOTT, J. (2012) Social network analysis, Thousand Oaks, Sage Publications.

SINCLAIR, D.; ZAIRI, M. (2001) An empirical study of key elements of total quality based measurement systems: a case study approach in the service industry sector. Total Quality Management, v. 12, n. 4, p. 535-50.

SMITH, A. D. (2011) Component part quality assurance concerns and standards: comparison of world-class manufacturers. Benchmarking: an international journal, v. 18, n. 1, p. 128-148.

SOHAL, A. S.; Terziovski, M. (2000) TQM in Australian manufacturing: factors critical to success, International Journal of Quality \& Reliability Management, v. 17, n. 2, p. 158-68.

SOUZA S. S.; LIMA, C. R. C. (2003) Maintenance focused on reliability as a strategic tool (in portuguese), in: Proceeding of the Encontro Nacional de Engenharia de Produção, Ouro Preto, Brazil, p. 1-8.

SVENSSON, M.; Klefsjo, B. (2001) Experiences from creating a quality culture for continuous improvements in Swedish School sector by using self-assessments, Total Quality Management, v. 11, n. 4-6, p. 800-807.

TANCO, M.; SANTOS, J.; RODRIGUEZ, J. L.; REICH, J. (2013) Applying lean techniques to nougat fabrication: a seasonal case study, The International Journal of Advanced Manufacturing Technology, v. 68, n. 5-8, p. 1639-1654.

THAKKAR J.; KANDA, A.; DESHMUKH, S. G. (2012) Supply chain issues in Indian manufacturing SMEs: insights from six case studies, Journal of Manufacturing Technology Management, v. 23, n. 5, p. 634-664.

TOHIDI, H.; KHEDRILIRAVIASL, K. (2012) Six sigma methodology and its relationship with lean manufacturing system, Advances in Environmental Biology, v. 6 , p. 895-906.

TYAGI, S.; CHOUDHARY, A.; CAI, X.; YANG, K. (2015) Value stream mapping to reduce the lead-time of a product development process, International Journal of Production Economics, v. 160, p. 202-212.

VIEIRA JUNIOR, M.; LUCATO, W. C.; VANALLE, R. M. (2014) Effective management of international technology transfer projects: Insights from the Brazilian textile industry, Journal of Manufacturing Technology Management, v. 25, n. 1, p. 69-99.

VINODH, S.; ARVIND, K. R.; SOMANAATHAN, M. (2010), Application of value stream mapping in an Indian camshaft manufacturing organization, Journal of Manufacturing Technology Management, v. 21, n. 7, p. 888-900.

VINODH, S.; SOMANAATHAN, M.; ARVIND, K. R. (2013) Development of value stream map for achieving leanness in a manufacturing organization, Journal of Engineering, Design and Technology, v. 11, n. 2, p. 129 - 141. 
VINODH, S.; DEVADASAN, S. R.; VIMAL, K. E. K.; KUMAR, D. (2013) Design of agile supply chain assessment model and its case study in an Indian automotive components manufacturing organization, Journal of Manufacturing Systems, v. 32, n. 4, p. 620-631.

WALTER, O. M. F. C.; TUBINO, D. F. (2004) Methods of evaluation of the implementation of lean manufacturing: a literature review and classification (in portuguese), Gestão \& Produção, v. 20, n. 1, p. 23-45.

WANG, C.; MING, X. G.; KONG, F. B.; LI, D.; WANG, P. P. (2011) Focus on implementation: a framework for lean product development, Forest Products Journal, v. 61, n. 5, p. 411-421.

WIENGARTEN, F.; PAGELL, M. (2012) The importance of quality management for the success of environmental management initiatives, International Journal of Production Economics, v. 140, n. 1, p. 407-415.

WORRELL, J.; WASKO, M.; JOHNSTON, A. (2013) Social network analysis in accounting information systems research, International Journal of Accounting Information Systems, v. 14, n. 2, p. 127-137.

XIE, W. (1995) How to implement world class operational management in effective way in the initial stage: a case study of Billerudkorsnäs, Degree project, in project management and operational development, Second level, Stockholm, Sweden.

YAMASHINA, H. (2000) Challenge to world-class manufacturing, International Journal of Quality \& Reliability Management, v. 17, n. 2, p. 132-143.

YIN, R. K. (2010) Case Study: design and methods, $4^{\text {th }}$, Porto Alegre, Bookman, 2010.

ZIMWARA, D.; GORIWONDO, W. M.; MHLANGA S.; CHASARA, T.; CHUMA T. (2012) World Class Manufacturing status assessment for a margarine producing company in Zimbabwe, International Journal of Innovative Technology and Exploring Engineering, v. 2, n. 1, p. 52-57.

ZULKIFFLI, S. N. A. (2010) The impact of supply chain operational capabilities on business performance of small and medium enterprises in Malaysia: a preliminary analysis, International Journal of Business and Management, v. 3, n. 2, p. 1. 